\title{
DOHH wt Allele
}

National Cancer Institute

\section{Source}

National Cancer Institute. DOHH wt Allele. NCI Thesaurus. Code C91280.

Human DOHH wild-type allele is located in the vicinity of $19 \mathrm{p} 13.3$ and is approximately 10 $\mathrm{kb}$ in length. This allele, which encodes deoxyhypusine hydroxylase protein, plays a role in the regulation of hypusine synthesis. 